\title{
EGFR Gene Amplification
}

National Cancer Institute

\section{Source}

National Cancer Institute. EGFR Gene Amplification. NCI Thesaurus. Code C36649.

A molecular genetic abnormality indicating the presence of multiple copies of the EGFR gene. 